\title{
What Affects Teaching and Research Behaviors: A Case of A University in China
}

\author{
Hong Ding \\ Zhejiang University of Finance and Economics, Hangzhou 310018, China \\ E-mail of the corresponding author: Dinghong@zufe.edu.cn
}

This research was supported by the Humanities and Social Science Foundation of Ministry of Education of China (Grant No. 17YJC880018)

\section{Abstract}

In order to analyze the preference of university teachers' teaching and research behavior, this research analyzes the influencing factors of teachers' teaching and research behaviors such as age, gender, professional title, degree, type of graduation universities based on discrete data analysis of teachers' actual workload in 12 years from a certain university in China. The study shows that the workload of teaching and research was significantly and positively affected by age. Professional title, degree and type of graduation universities have no significant impact on the teaching workload, but have a significant impact on the research workload. The proportion of teachers' workload between teaching and research will also be affected by gender, degree and type of graduation universities. The results also show that doctoral teachers who graduated from First-class universities and Firstclass discipline universities are not outstanding in research.

Keywords: university teachers, teaching and research behaviors, influencing factors, discrete data analysis

DOI: $10.7176 / \mathrm{JEP} / 12-33-02$

Publication date: November $30^{\text {th }} 2021$

\section{Introduction}

The continuous development of social demand has imperceptibly changed the mission and function of universities, and the function of higher education will inevitably develop from pure knowledge transmission to a comprehensive direction of knowledge inheritance and innovation. This requires university teachers not only to be good at teaching, but also to make achievements in research. In this instance, university teachers will be inevitably under the pressure of the allocation of time, energy and other resources in teaching and research. Due to the imbalance and incompleteness of the evaluation system and assessment indicators, it has been criticized that China's colleges and universities despise teaching but attach great importance to research for a long time. According to the current domestic situation, the top-down, fixed and research-oriented evaluation indicators have restricted the willingness of universities to innovate the evaluation system. Therefore the internal evaluation of universities becomes a management evaluation instead of academic evaluation. Under this guidance, university teachers have obvious biases when choosing teaching and research behaviors. Subsequently, the problem of balance between teaching and research also arises. Among the university teachers, some have outstanding performance in both teaching and research, and some have better performance only in teaching or only in research.

However, university management usually applies the research performance as the main indicator in the reward performance, annual assessment, professional title promotion of the teachers and even university quality evaluation. This has greatly guided a large number of teachers to pay more attention to research and despise teaching, which has a great impact on the function of university's teaching and educating students. At the same time, the excessive pressure of research also leads to teachers' fatigue to cope with the task of research assessment. The innovation of task-based research is much lower than that of spontaneous research or nonassessment target-driven research, which, to a certain extent, leads to the lack of innovation capabilities of the entire university. From the perspective of government management, the reform of educational evaluation has risen to national behavior. Changing the phenomenon of overemphasizing research and neglecting teaching is one of the important contents of educational evaluation reform. An important reform goal of the "Deepening the Reform of Education Evaluation in the New Era" issued by the Central Committee of the Communist Party of China and the State Council (October 2020) is to eliminate behaviors such as emphasizing research and neglecting teaching, and emphasizing teaching and neglecting educating students and so on.

In recent years, the Ministry of education, the Ministry of science and technology and other national ministries and commissions of China have also successively issued a series of policy documents aimed at optimizing research evaluation and strengthening teaching quality. Some universities also have gradually incorporated teaching performance into evaluation indicators in accordance with the requirements of the government documents. This shows that both the government and universities have fully realized that teaching should have a more prominent position in higher education than at present. In this context, based on the actual data, this paper will analyze the influencing factors of university teachers' teaching and research behaviors and 
the choice behavior between them, and discuss how to promote the coordinated development of them.

\section{Literatures review}

During the formation and development of Western classical universities (from the 12th century to the early 19th century), the production and promotion of knowledge were not mainly undertaken by the same institution, and the main function of university was to engage in the dissemination of knowledge (Tan 2008). In terms of research, scientific organizations such as the Royal Society are committed to scientific experimentation and scientific innovation, and have made extraordinary achievements in astronomy, geography, mathematics, and medicine. In 1810, the establishment of Berlin University marked the rise of modern universities and became a milestone in the history of human education and scientific development. One of the outstanding characteristics was that scientific research entered the University and realizes institutionalization. Modern university has become a knowledge place for the combination of teaching and research. University teachers also had two responsibilities: teaching and research. After that, the academic circles of higher education also generally believed that the integration of teaching and research was inevitable in the development of universities. Jaroslav Pelikan believed that the responsibilities of the university included several aspects. They promoted knowledge through undergraduate and graduate teaching, advance knowledge through research, preserve knowledge in libraries and museums, and disseminate knowledge through academic publications (Jaroslav 2014). The first two can be called teaching and research respectively. The experience of universities in Germany, the United States and Britain also shows that supporting the training of talents through high-level scientific research has become the key to comprehensively improve the quality of higher education.

The reasonable determination of the relationship between teaching and research in higher education is related to the position and development of the university itself, the role of supporting technology and social development. The continuous evolution of university function also determines the continuous change of the relationship between teaching and research within the university, and the status of university teachers has also been constantly changing. The teaching and academic status of teachers is largely determined by the university's own functional positioning. Once the university itself define its own teaching and research function, it will inevitably transfer the corresponding tasks to teachers, so that teachers have the identity of teaching and academic research at the same time. Since the 1950s and 1960s, there have been many papers at home and abroad discussing the relationship between university teachers' teaching status and academic status. But so far, there is still no clear and generally agreed conclusion. Burton Clark believed that in modern university education, there was no problem more fundamental than the relationship between teaching and research, and there was no problem with such superficial ideas and retrogressive criticism inside and outside the academic community (Burton 1997). Huang Yating analyzed the influence of factors such as organization, discipline, and individual on the identity of university teachers. She pointed out that the academic community has became more like a competitive and market-oriented corporate environment. Knowledge commoditization was becoming more and more obvious. Individual university teachers were under the pressure from research evaluation, various rankings and academic publication, having an impact on teachers' teaching or academic identity positioning (Huang 2015). Some scholars have also studied the relationship between teaching and research. Wu Hongfu combed the historical development of the relationship between teaching and research in Chinese universities. He pointed out that with the deepening of the research on the relationship between teaching and research, people had increasingly realized that the relationship between education and scientific research was complex, historical and conditional (Wu 2011). Some scholars believed that teaching and research in universities did not always promote each other. For example, Boyer put forward that teaching was also a complex research behavior. He also believed that the types of universities had become more and more diverse (National Education Development Research Center 1994). The social functions performed by universities were different, but in fact, the functions set by many universities for themselves tend to be homogenized. The mission of research has become more and more generalized to universities at all levels, which has led to the squeeze of research in the field of higher education on teaching. Zhao Tingting believed that teaching and research had a relatively coordinated stage in the history of university development, but in general, there were more contradictions than coordination. Moreover, the new contradictions generated on the basis of continuous coordination seemed to be more acute and intense (Zhao 1992). Kelly Coate believed that although the education community generally knew that teaching and research should have a positive relationship, in fact, there was a negative and even separation relationship between them. The main influencing factors of this phenomenon were the pressure of balanced investment in education and research, the limited time of academic staff, the competitiveness of scarce resources and so on (Kelly 2001). Feldman believed that the relationship between them was small, and it was not statistically significant (Feldman 1987). Marsh also believed that the relationship between them was almost close to zero (John 1996). Of course, many scholars believed that scientific research should be able to enrich teaching content and improve teaching quality. Teachers could explore new fields and acquire new knowledge through research, and then pass the new knowledge to students through the classroom. At the same time, students could 
participate in the process of research and develop the habit of innovation and learn innovative methods from this process gradually. Through interviews with professors and managers of eight high-level universities, Yu Xiulan concluded that teaching and research always had conflict in time, but in essence they could promote each other (Yu 2008). However, from the domestic reality, whether it is the government management department or the social evaluation agency, the evaluation of universities has always been more focused on scientific research than teaching. This has already shown that evaluation subjects have recognized that teaching and research are the main functions of the university, and at the same time it is assumed that they promote each other.

Most of the research on the relationship between teaching and research is an exploration of concept cognition. In practice, what are the factors that affect teachers' behavior and their preference? Age, education level, graduation university, professional title and the institutional environment may affect the active or passive performance of university teachers in teaching and research. Some domestic scholars have carried out empirical research in this area. Zhao Shihua et al. conducted a questionnaire on 381 female teachers, made an empirical analysis on the factors affecting female teachers' teaching and research enthusiasm, and concluded that ideological, cultural life, teaching pressure and research pressure were the main factors. In addition, the pressure of professional title evaluation was also an important factor affecting the development of female teachers (Zhao 2010). Chen Jing et al. conducted a questionnaire on 301 teachers in a teaching university. She believed that the working atmosphere and policy orientation of teachers' university were the main factors affecting their behaviors (Chen 2014). Niu Fengrui et al. also used a questionnaire survey to analyze the influence of age, educational background, gender on university teachers' teaching and research preferences. The results showed that gender was an important factor affecting the preference. The proportion of male teachers who preferred research was significantly higher than that of female teachers, and the proportion of female teachers who preferred teaching was significantly higher than that of male teachers (Niu 2017).

In addition, age and educational background would also have a certain impact. Brew, Robertson and Bond pointed out that the relationship between teaching and research would change with different environments, and the level of discipline and academic education affected teaching and research behavior (Brew 1999)(Jane 2005). Becher, Trowler and Trigwell believed that due to differences in the epistemology, research methods, types of academic activities, and culture of each discipline, the connection between teaching and research in each discipline may be different (Tony 2001)(K 2005). Fairweather, Ramsden and Moses believed that the relationship between teaching and research was different by the relationship between teachers' personal teaching ability and scientific research ability (James 2002) (Paul 1992).

The research on the relationship between age and research performance is controversial. Some scholars believe that young teachers have better scientific research performance because they have been systematically trained in the latest research methods. Some scholars believe that older teachers have richer experience and broader professional knowledge, so they will perform better in research. Baldwin et al., Blackburn and Lawrence believed that there was no simple linear relationship between scientific research performance and age, and that the relationship between them may vary with changes in academic career stages (RG 2005) (Robert 1986). Bonaccorsi believed that only the age of high-level researchers had no significant relationship with the output of scientific research results, while other groups had a negative relationship (Andrea 2003).

From the above literature review, we find that more research at home and abroad focused on the relationship between teaching and research, which also focused on the current situation description and policy suggestions at present, while there is a relative lack of empirical research on the influencing factors of teaching and research behavior. Most of the domestic empirical research data was obtained based on questionnaire, and there was little empirical researches supported by the actual output data of teachers' teaching and research. At the same time, most of the existing studies analyzed the research behavior, the influencing factors of research output or the correlation between teaching and research. And there was little research on the influencing factors of teaching behavior. However, in practice, some factors may have an impact on both teaching and research behavior at the same time. Therefore, based on the 12-year workload data of teaching and research of a university teacher group, this research intends to deeply analyze the influence mechanism of age, professional title, degree, type of graduation school and other factors on teachers' teaching and research preference behavior through descriptive statistical analysis and multiple linear regression analysis. Further, policy recommendations are put forward.

\section{Analysis on the influence mechanism of university teachers' teaching and research behaviors}

After reviewing the literature, we found that the education circles generally have a relatively consistent understanding of the relationship between university teaching and research. As for what are the factors affecting the relationship between them, there are still relatively few empirical studies on the whole, and the existing studies are also analyzed from a relatively single perspective.

From the perspectives of teachers' age, degree, type of graduation university, professional title and the institutional environment in which they are located, this article intends to analyze the factors affecting the 
relationship between university teaching and research based on workload data for 12 consecutive years and combined with the changes of external and internal institutions of the University.

\subsection{Age}

Age is an important factor affecting university teachers' teaching and research behavior. So, does research have a basic life cycle like most jobs? Are the rising and peak periods of vitality of the research community significantly concentrated in a certain age group? Many universities also clearly realize that they need more young and middle-aged teachers to undertake more research tasks, for these teachers have better vitality to carry out research activities, investigation and practical action. Therefore, academics are also under pressure, and their institutions will require them to retire early to save costs and create jobs for new graduates (Robert 1986). Some national scientific research projects have clear age limits. For example, applicants for the National Natural Science Foundation of China are generally no more than 35 years old for man and 40 years old for women. And applicants for the National Philosophy and Social Science Fund are generally no more than 35 years old. Some national talent projects and provincial and ministerial talent plans also have age regulations. Age anxiety can be said to accompany all researchers in universities. If young and middle-aged teachers pay more attention to research experience at the beginning of their career, and universities do not require teaching work at the initial stage of teachers. After they have accumulated a certain amount of research, teachers can better engage in teaching work. Under this assumption, the relationship between teaching and research may appear as shown in Figure 1.

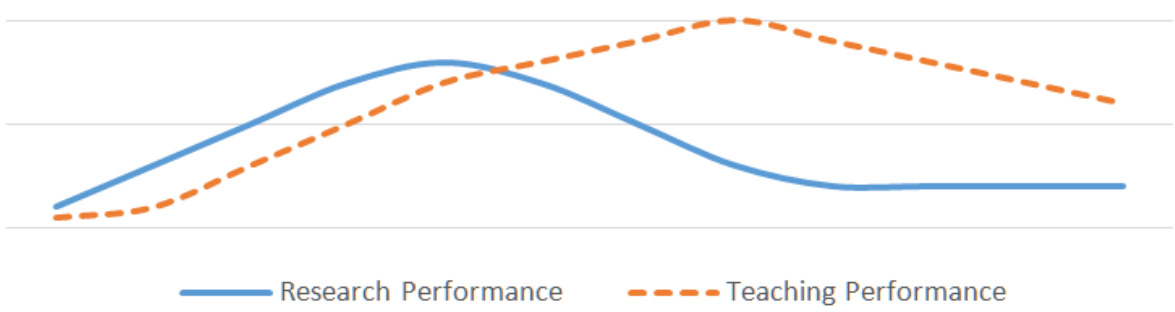

Figure 1. Time Relationship Between Changes in Teaching and Research Performance

In Figure 1, the horizontal coordinate represents the age, and the right coordinate represents the age growth. The vertical coordinate indicates the research output and teaching performance, and the upward coordinate indicates that the research and teaching performance are better. At the same time, the increase of research output is ahead of the improvement of teaching performance, and the improvement of teaching ability shows a certain lag.

3.2 Degree/Graduation school level

In 2017, the Ministry of International Education, the Ministry of Finance, and the National Development and Reform Commission of China issued the "Measures for Coordinating the Implementation of the Construction of First-Class Universities and First-Class Disciplines" to promote the double first-class plan. The first batch of double first-class universities totaled 137, including 42 first-class universities and 95 first-class discipline universities. The selection was mainly based on talent training, team construction, scientific research contribution and some other aspects. Therefore, being selected as a double first-class university represents its high level in teaching, scientific research and talent cultivation.

In the current undergraduate universities, teachers with doctoral degrees have become the main part of the faculty. According to statistics, in 2014, the proportion of university teachers with doctoral degrees in China was only $20.05 \%$. In recent years, this proportion has continued to grow. In economically developed areas such as Zhejiang Province, the doctoral rate of university teachers has reached 60\%-70\%. Compared with masters and undergraduates, Ph.D. teachers who have received more systematic research training may have more advantages in scientific research awareness and scientific research level. Under the above assumptions, the teaching and research performance of $\mathrm{PhD}$ or high-level university teachers may be as shown in Figure 2 . 


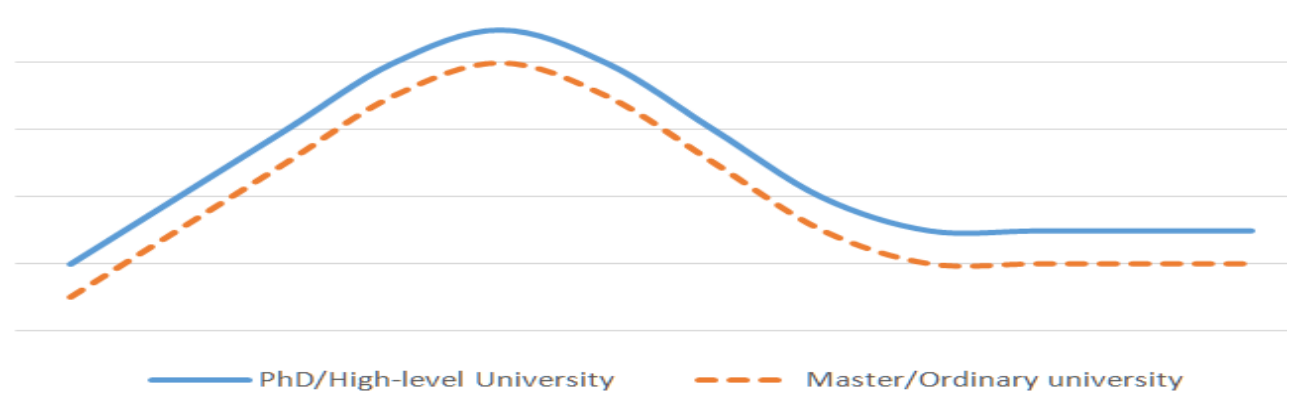

Figure 2. Comparison of Teaching and Research Performance of Teachers at Different Levels of Degree and Graduation Schools

\subsection{Professional title}

The promotion of professional titles requires the support of teaching and research results. Therefore, it is the most important factor driving teachers' behaviors. However, a major problem currently existing is that there are obvious differences in the teaching and research behaviors of teachers before and after the promotion of professional titles. Tien believed that academic level affected research performance (Tien 2007). After the promotion of academic level, the speed of research output would be slower. Due to the inconsistent assessment requirements of professional title promotion on teaching and research, teachers' choices of teaching and research behavior are obviously different before and after professional title promotion.

\subsection{Policy and system environment}

The choice of teachers' teaching and research behaviors is also largely affected by policy and system environment. For example, many universities have adopted the "up and down" system of professional titles, which plays a great guiding role in teachers' choice behavior. Teachers who have not completed the tasks set of their posts will be "high-level and low-employment", which will happen when the posts are insufficient. This encourages teachers to do their best to complete more tasks and not be included in the low employment when ranking their performance. Of course, performance ranking is a fair evaluation method. But how to formulate scientific and reasonable tasks and the balance between teaching tasks and research tasks have become the main problems. These are important factors affecting teachers' teaching and research behavior.

\section{Data sources and research methods}

The data of this research is from $\mathrm{Z}$ University, which established a quantitative evaluation mechanism for teaching and research as early as 2008 , and set quantitative standards for teaching work such as classroom teaching and research work such as research papers. Among them, the teaching workload includes classroom work, tutor work, guiding students outside the classroom, teaching rewards and punishments, teaching construction and awards, etc. The research workload includes research papers, government-aided projects, enterprise-aided projects, works, awards and achievement transformation.

Based on the quantitative data of teaching and research work of Z University from 2008 to 2019, this study discusses the impact of age, professional title, degree and type of graduation university on the change of teaching and research workload. The data has a total of 7171 items, which is discrete, including the teaching workload and research workload of all teachers in University $\mathrm{Z}$ over the past 12 years, covering all teachers engaged in teaching and research work in the school. The university is a provincial key construction university, has the qualification to grant doctorate degrees, and has a good level of teaching and research. Therefore, the data has a good comprehensiveness and representativeness.

Table 1. Description of Related Variables

\begin{tabular}{c|c|c}
\hline & Variable name & Variable description \\
\hline \multirow{4}{*}{ Dependent variable } & Research workload & Total amount of scientific research work, continuous variable \\
\cline { 2 - 3 } & Teaching workload & Total amount of teaching work, continuous variable \\
\cline { 2 - 3 } & $\begin{array}{c}\text { Proportion of teaching } \\
\text { work }\end{array}$ & $\begin{array}{c}\text { Proportion of teaching workload in total workload, } \\
\text { continuous variable }\end{array}$ \\
\hline \multirow{4}{*}{$\begin{array}{c}\text { Independent } \\
\text { variable }\end{array}$} & Gender & Categorical variable \\
\cline { 2 - 3 } & Age & Continuous variable \\
\cline { 2 - 3 } & Professional Title & Categorical variable \\
\cline { 2 - 3 } & Degree & Categorical variable \\
\cline { 2 - 3 } & $\begin{array}{c}\text { Type of graduation } \\
\text { school }\end{array}$ & Categorical variable \\
\hline
\end{tabular}


The variables are described in Table 1. The proportion of teaching work is the proportion of teaching workload in the total amount of teaching and research work. Taking this as the dependent variable, this paper analyzes the relationship between independent variables and it, and judges the influence of gender, age, professional title, degree, type of graduation school and others on Teachers' choice of teaching and research behavior. The analysis method mainly adopts descriptive statistical analysis and multiple linear regression analysis.

\section{Empirical results and analysis}

Table 2 is the composition of the data sample, describing the distribution of male and female teachers in terms of age, professional title, degree, and type of graduation university. It is not only the composition of samples, but also the statistical description of variables. As shown in the table 2, the average age of female teachers is nearly 3 years lower than that of males. The proportion of female professors is much lower than that of males. The proportion of female teachers with doctoral degrees is much lower than that of males. The proportion of male and female teachers who graduated from first-class universities and first-class discipline universities is relatively close. It can be seen that the structural position occupied by female teachers is significantly lower than that of males (Zhu 2014).

Table 2. Sample Composition

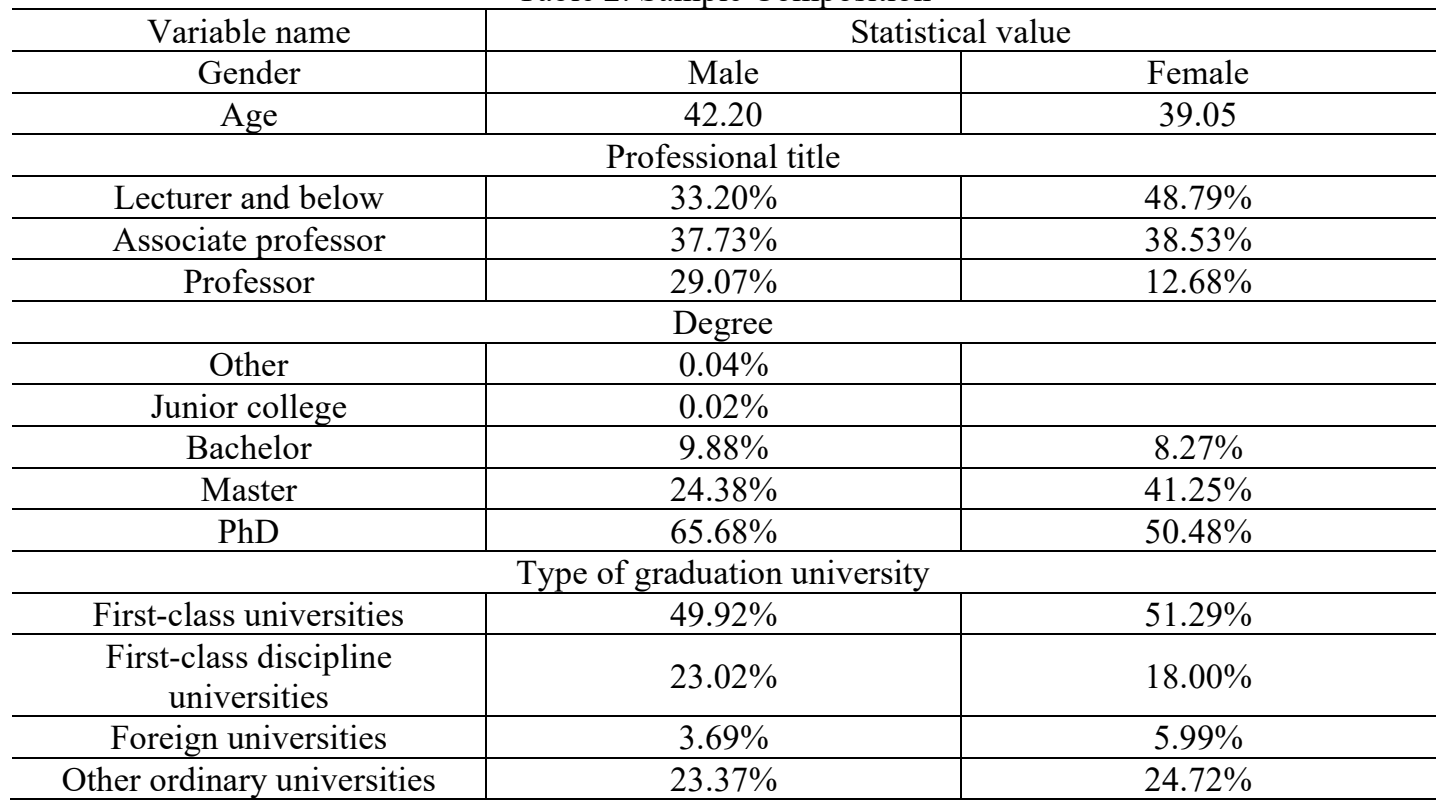

Table 3 is a descriptive statistics of the workload of teaching and research in Z University. The table shows the relevant data of teaching workload, research workload and the proportion of teaching workload according to classified variables.

Table 3. Description and Statistics of Teaching and Research Workload in Z Universities

\begin{tabular}{c|c|c|c|c|c|c|c|c|c}
\hline & $\begin{array}{c}\text { Research } \\
\text { workload }\end{array}$ & $\begin{array}{c}\text { Teaching } \\
\text { workload }\end{array}$ & $\begin{array}{c}\text { Teaching } \\
\text { proportion }\end{array}$ & $\begin{array}{c}\text { Research } \\
\text { workload }\end{array}$ & $\begin{array}{c}\text { Teaching } \\
\text { workload }\end{array}$ & $\begin{array}{c}\text { Teaching } \\
\text { proportion }\end{array}$ & $\begin{array}{c}\text { Research } \\
\text { workload }\end{array}$ & $\begin{array}{c}\text { Teaching } \\
\text { workload }\end{array}$ & $\begin{array}{c}\text { Teaching } \\
\text { proportion }\end{array}$ \\
\hline & Mean & Mean & Mean & Max & Max & Max & Min & Min & Min \\
\hline $\begin{array}{c}\text { Lecturer } \\
\text { and below }\end{array}$ & 129.7 & 338.4 & 0.8 & $3,000.00$ & $1,777.00$ & 1 & 0 & 0 & 0 \\
\hline $\begin{array}{c}\text { Associate } \\
\text { professor }\end{array}$ & 223.4 & 413.4 & 0.8 & $5,940.00$ & $1,702.00$ & 1 & 0 & 0 & 0 \\
\hline Professor & 453.7 & 376.7 & 0.6 & $8,850.00$ & $2,281.00$ & 1 & 0 & 0 & 0 \\
\hline Total & 234.9 & 375.2 & 0.7 & $8,850.00$ & $2,281.00$ & 1 & 0 & 0 & 0 \\
\hline PhD & 349.2 & 355.2 & 0.7 & $8,850.00$ & $2,281.00$ & 1 & 0 & 0 & 0 \\
\hline Bachelor & 80.8 & 404 & 0.9 & $2,049.00$ & $1,526.00$ & 1 & 0 & 0 & 0 \\
\hline Other & 0 & 16 & 1 & 0 & 16 & 1 & 0 & 16 & 1 \\
\hline Junior college & 0 & 323 & 1 & 0 & 323 & 1 & 0 & 323 & 1 \\
\hline Master & 70.8 & 403.6 & 0.9 & $2,220.00$ & $1,777.00$ & 1 & 0 & 0 & 0 \\
\hline Total & 234.9 & 375.2 & 0.7 & $8,850.00$ & $2,281.00$ & 1 & 0 & 0 & 0 \\
\hline
\end{tabular}




\begin{tabular}{c|c|c|c|c|c|c|c|c|c}
\hline & $\begin{array}{c}\text { Research } \\
\text { workload }\end{array}$ & $\begin{array}{c}\text { Teaching } \\
\text { workload }\end{array}$ & $\begin{array}{c}\text { Teaching } \\
\text { proportion }\end{array}$ & $\begin{array}{c}\text { Research } \\
\text { workload }\end{array}$ & $\begin{array}{c}\text { Teaching } \\
\text { workload }\end{array}$ & $\begin{array}{c}\text { Teaching } \\
\text { proportion }\end{array}$ & $\begin{array}{c}\text { Research } \\
\text { workload }\end{array}$ & $\begin{array}{c}\text { Teaching } \\
\text { workload }\end{array}$ & $\begin{array}{c}\text { Teaching } \\
\text { proportion }\end{array}$ \\
\hline $\begin{array}{c}\text { Other ordinary } \\
\text { universities }\end{array}$ & 176.7 & 363.8 & 0.8 & $5,459.00$ & $1,777.00$ & 1 & 0 & 0 & 0 \\
\hline $\begin{array}{c}\text { First-class discipline } \\
\text { universities }\end{array}$ & 239.7 & 393.7 & 0.8 & $8,850.00$ & $1,378.00$ & 1 & 0 & 0 & 0 \\
\hline $\begin{array}{c}\text { First-class } \\
\text { universities }\end{array}$ & 265.1 & 376 & 0.7 & $7,275.00$ & $2,281.00$ & 1 & 0 & 0 & 0 \\
\hline $\begin{array}{c}\text { Foreign } \\
\text { universities }\end{array}$ & 187.2 & 342.4 & 0.8 & $3,660.00$ & $1,075.00$ & 1 & 0 & 0 & 0 \\
\hline Total & 234.9 & 375.2 & 0.7 & $8,850.00$ & $2,281.00$ & 1 & 0 & 0 & 0 \\
\hline
\end{tabular}

5.1 Analysis of influencing factors of teaching workload

According to the regression results of teaching workload in Table 4, we can see that the teaching workload is significantly positively affected by age. As age increases, the absolute value of teaching workload will increase. This shows that with the growth of age, the amount of teaching work undertaken by teachers as a whole is showing an increasing trend. Title, degree and the type of graduation university have no significant influence on the value of teaching workload. The level of them will have not a significant common change in the teaching workload.

Table 4. Basic Regression Results of the Factors Affecting the Workload of Teaching and Research in Universities

\begin{tabular}{|c|c|c|c|}
\hline & $\begin{array}{c}\text { (1) } \\
\text { Teaching workload }\end{array}$ & $\begin{array}{c}\text { (2) } \\
\text { Research workload }\end{array}$ & $\begin{array}{c}\text { (3) } \\
\text { Teaching proportion }\end{array}$ \\
\hline \multirow[t]{2}{*}{ Age } & $21.861 * * *$ & $10.350 * * *$ & $0.006^{* * *}$ \\
\hline & $(25.518)$ & $(5.981)$ & $(6.262)$ \\
\hline \multirow[t]{2}{*}{ Professor } & 22.462 & $296.340 * * *$ & -0.020 \\
\hline & $(1.192)$ & (7.784) & $(-0.872)$ \\
\hline \multirow[t]{2}{*}{ Associate professor } & 17.206 & $104.734 * * *$ & -0.016 \\
\hline & $(1.541)$ & (4.642) & $(-1.198)$ \\
\hline \multirow[t]{2}{*}{ Male } & -24.423 & -154.209 & $0.558 * * *$ \\
\hline & $(-0.156)$ & $(-0.489)$ & $(2.935)$ \\
\hline \multirow[t]{2}{*}{$\mathrm{PhD}$} & -40.834 & 28.839 & $-0.195 * *$ \\
\hline & $(-0.507)$ & $(0.177)$ & $(-2.009)$ \\
\hline \multirow[t]{2}{*}{ Master } & 1.148 & 48.835 & -0.077 \\
\hline & $(0.019)$ & $(0.409)$ & $(-1.079)$ \\
\hline \multirow{2}{*}{ First-class universities } & 59.724 & -24.632 & 0.023 \\
\hline & $(1.032)$ & $(-0.211)$ & $(0.330)$ \\
\hline First-class discipline & 51.205 & $-414.779 * * *$ & $0.249 * * *$ \\
\hline universities & $(0.756)$ & $(-3.030)$ & $(3.094)$ \\
\hline \multirow{2}{*}{ Foreign universities } & 13.190 & $-174.245^{*}$ & 0.017 \\
\hline & $(0.294)$ & $(-1.924)$ & $(0.315)$ \\
\hline \multirow{2}{*}{ _cons } & $-531.503 * * *$ & -133.723 & $0.273^{*}$ \\
\hline & $(-4.535)$ & $(-0.565)$ & $(1.922)$ \\
\hline $\mathrm{N}$ & 7171 & 7171 & 7171 \\
\hline
\end{tabular}

Note: Professional title: lecturer and below as the reference group; Gender: female as the reference group; Type of graduation university: other ordinary universities as the reference group. Significance: ${ }^{*} \mathrm{P} \leq 0.05,{ }^{*} * \mathrm{P} \leq 0.01$, $* * * \mathrm{P} \leq 0.001$

\subsection{Analysis on influencing factors of research workload}

The second column of Table 4 is the regression result of research workload. According to the results, the workload of research is not only positively affected by age, but also by title and the type of graduation university. The higher the title means the higher the output of research. However, the first-class disciplines and foreign universities have a significantly negative impact on the workload of research.

5.3 Analysis on the proportion of teaching workload

It can be seen from the third column of Table 4 that the proportion of teaching increases as age increases in terms of workload distribution. This shows that, on the whole, the older the age, the more teachers pay attention to 
teaching, and there are differences in the overall growth trend of teaching and research. The teaching proportion of men is higher than that of women, the teaching proportion of $\mathrm{PhD}$ is lower than that of teachers with other degrees, and the teaching proportion of teachers who graduated from first-class discipline universities is higher than that of other schools.

5.4 Interaction between degree and type of graduation university

According to the regression results in Table 4, the interactive items of degree and type of graduation university are added to the model. The results are as shown in table 5. From this table, the type of graduation university has a moderating effect on the teaching work and the proportion of teaching workload of PhD teachers. The absolute teaching workload value of $\mathrm{PhD}$ teachers who graduated from first-class universities is significantly lower than that graduating from other types of universities. And the teaching proportion of PhDs who graduated from firstclass universities and foreign universities is significantly lower than that of other teachers.

Table 5. Degree Heterogeneity of Influencing Factors of Teaching and Research Workload in Universities

\begin{tabular}{cccc} 
& $(1)$ & $(2)$ & $(3)$ \\
& Teaching workload & Research workload & Teaching proportion \\
\hline Age & $21.835^{* * *}$ & $10.368^{* * *}$ & $0.006^{* * *}$ \\
Professor & $(25.483)$ & $(5.988)$ & $(6.211)$ \\
& 23.323 & $295.423^{* * *}$ & -0.018 \\
Associate professor & $(1.237)$ & $(7.757)$ & $(-0.802)$ \\
& 17.504 & $104.333^{* * *}$ & -0.016 \\
Male & $(1.568)$ & $(4.624)$ & $(-1.168)$ \\
& 80.656 & -278.616 & $(3.659)$ \\
PhD & $(0.498)$ & $(-0.851)$ & -0.015 \\
& 52.339 & -71.219 & $(-0.123)$ \\
Master & $(0.528)$ & $(-0.356)$ & -0.080 \\
& -2.317 & 53.761 & $(-1.121)$ \\
First-class universities & $(-0.039)$ & $(0.449)$ & $0.248^{* *}$ \\
& $202.826^{* *}$ & -204.010 & $(2.325)$ \\
First-class discipline universities & $(2.267)$ & $(-1.128)$ & 0.200 \\
& -6.719 & -331.235 & $(1.617)$ \\
Foreign universities & $(-0.066)$ & $(-1.598)$ & $0.164 * *$ \\
& 82.606 & $-238.460 *$ & $(2.067)$ \\
First-class universities_PhD & $(1.256)$ & $(-1.794)$ & 0.019 \\
First-class discipline universities & 54.873 & -86.896 & $(0.125)$ \\
PhD & $(0.447)$ & $(-0.350)$ & $-0.343^{* * *}$
\end{tabular}

5.5 Promoting effect of research on Teaching

The least square method is used to linearly fit the per capita workload of teaching and research from 2008 to 2019. The analysis found that the teaching workload increased significantly in 2013. Due to the diversion of the proofreading teachers in 2013, nearly one-fifth of the teachers were diverted to other college, and the number of students has not changed, the per capita teaching workload has increased significantly. Therefore, we analyzed the changes of teaching workload from 2008 to 2013 and after 2013. From the perspective of workload, the improvement of research ability does not have a positive effect on the workload of classroom teaching. This improvement effect is mainly reflected in improving students' ability, such as guiding students to win science and technology competition awards, guiding students to win science and technology projects, etc. These are incorporated into the teaching work and calculate the workload. At the same time, considering that the improvement of research ability promotes the improvement of teaching and there is a time lag, so the analysis of teaching data lags behind research data by two years. 


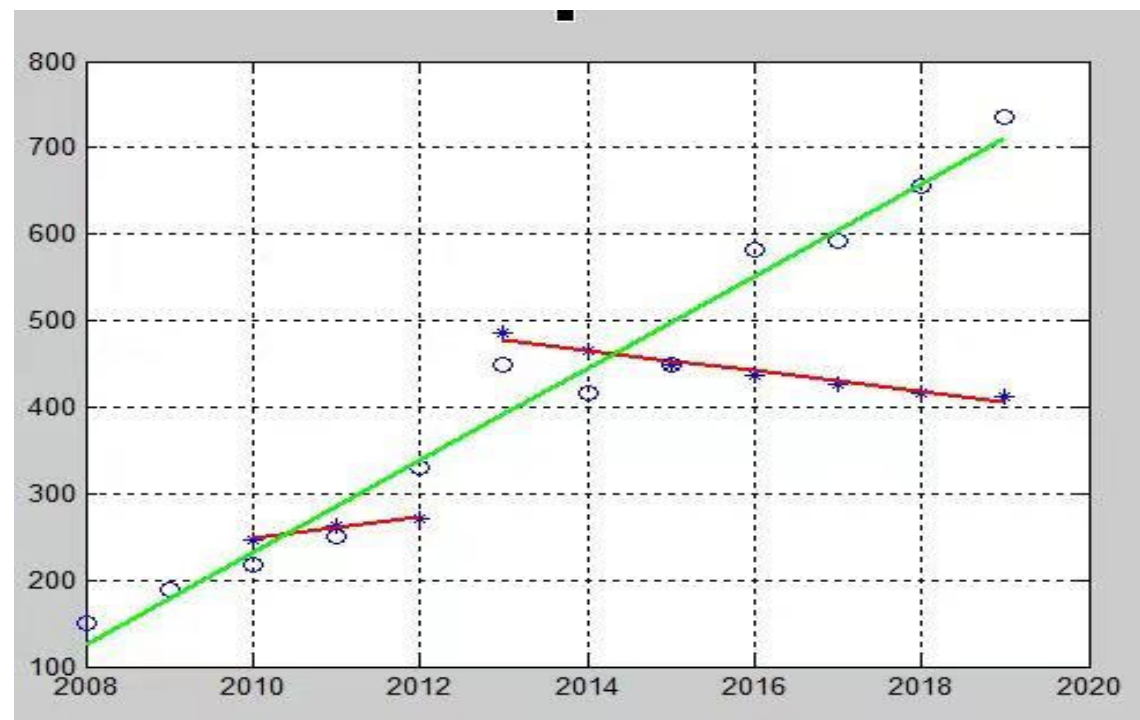

Figure 3. Fitting Line of Teaching and Research Workload from 2008 to 2019

In Figure 3, the ordinate value corresponding to the dot represents the per capita workload of research, and the ordinate value corresponding to the asterisk represents the per capita workload of teaching. The slope of the fitted curve represents the respective change rate. From 2008 to 2019, the per capita workload of research shows a stable upward trend. Before 2013, the per capita workload of teaching shows an upward trend and a downward trend after 2013.The university has a fixed number of requirements for teachers' teaching classroom workload, and the per capita classroom workload of teachers is stable every year. Therefore, the decline of per capita teaching workload is due to the decline of work output of guiding students outside the classroom. It can be seen that research in the early stage promoted teaching to a certain extent, but there has been a certain reverse effect in the later stage.

5.6 The influence of policy change on teachers' research

From 2008 to 2019, the per capita workload of research has shown a steady upward trend. From a policy perspective, since 2008, the university has mainly used research indicators in four aspects: post assessment, professional title evaluation, workload incentive and project funding. After systematic sorting, the relevant systems of workload incentive and project funding have been adjusted for many times, and the incentive and funding have been gradually reduced. For example, the funds for national projects were adjusted from providing the same amount of supporting funds as appropriation to completely canceling the supporting funds. The incentive for the publication of research papers has also been declining. The research indicators in post assessment and professional title evaluation are relatively stable, but the promotion of teachers is becoming more and more difficult due to the limitation of the rated number of posts. In fact, the requirements for research indicators to achieve promotion are getting higher and higher. Therefore, it can be considered that the internal pressure of assessment and promotion is the main factor to promote teachers' research behavior, while the promotion effect of reward is not obvious. Figure 4 shows the author's questionnaire survey of 621 teachers in 15 colleges and universities. The results also verify this view.

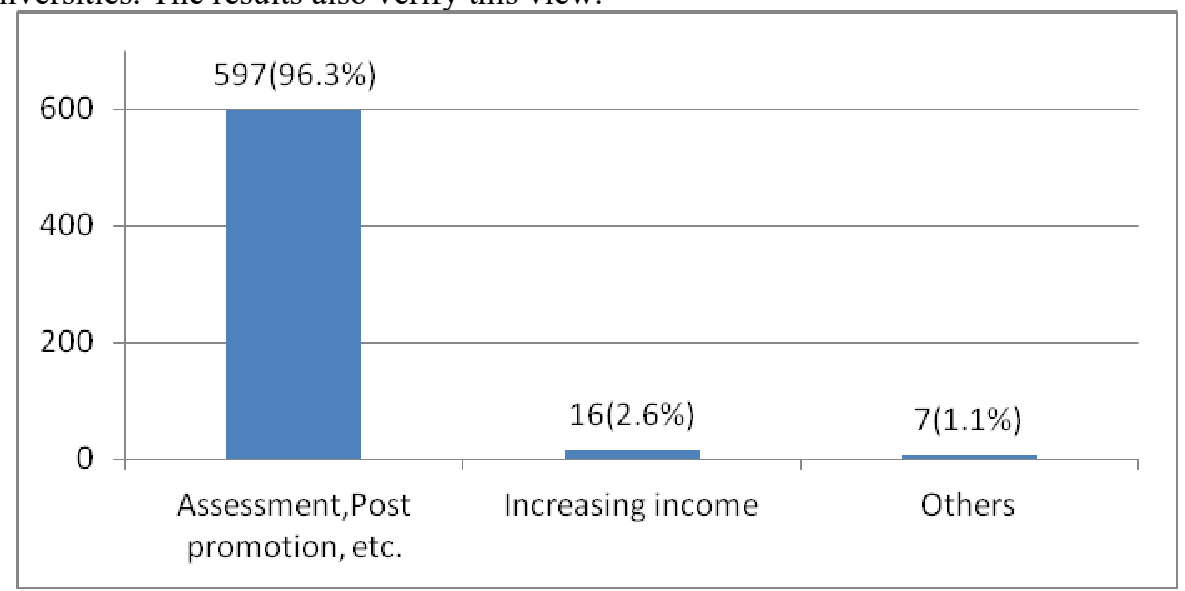

Figure 4. Investigation on Motivation of Research Behavior 


\section{Conclusions and recommendations}

From the individual point of view, the teaching workload and research work increase significantly with the growth of teachers' age. On the whole, older teachers undertake more teaching and research work than young teachers. With the increase of age, the proportion of teachers' teaching work also increases. This seems to be in line with general experience and the expectations of most universities for the development of the faculty. It is also a data demonstration of the view that teaching is not contradictory to research. When the University introduces teachers, it will sign a contract to specify the six-year service period and assessment tasks. The assessment only stipulates the basic teaching workload for teaching. The teachers can choose not to undertake classroom teaching tasks in the first three years, but they must complete more research tasks. In order to promote the coordinated development of teaching and research, the university has also formulated the equivalent evaluation and identification method for teaching and research work, and achieved the equivalent identification of all teaching and research in the evaluation work such as assessment and professional title evaluation. This ensures that teachers can pay equal attention to teaching and research work. Therefore, it can be seen that a scientific and reasonable teacher assessment mechanism and management system are important means for the coordinated development of teaching and research work.

However, the data also shows that with the continuous development of research work, the per capita workload of teaching has decreased, mainly due to the decline in the teaching work of teachers guiding students. The attractiveness of research output is more lasting than the attractiveness of teaching output, and teachers are willing to put more energy on research work. Therefore, in terms of stimulating the vitality of teachers' work, the system should be designed with more consideration of teachers' long-term career development, and resolve teachers' worries that too much teaching work may be ignored in the future. In addition, in terms of retirement policies, it is possible to explore further relaxation of regulations, to extend the range of retirees appropriately, and to allow high-level talents to play their roles fully with the consent of individuals.

Second, the study found that the workload of research is greatly affected by both the professional title and the graduate school. There is a positive correlation between teachers' professional titles and research workload. This is basically consistent with the expectations of the university. Universities have post assessment tasks for teachers. The post grade is linked to the professional title grade. The higher the post means the heavier the post assessment task. However, the research shows that in the research workload of graduates from first-class discipline universities and foreign universities is significantly lower than that of domestic ordinary university graduates. The research workload of teachers who graduated from first-class universities is not significantly different from that of ordinary university graduates. There is no significant difference in the research workload of teachers with doctor degrees who graduated from first-class universities, first-class discipline universities , foreign universities and other ordinary universities. It can be seen that for teachers with doctoral degrees, the level of graduation university does not play a regulatory role in research performance. Like other similar universities, most of the teachers introduced by this university over the years have graduated from first-class discipline universities or first-class universities, with the purpose of improving the comprehensive strength more quickly. From the data analysis, this team did not play a good supporting role. This also shows that it is necessary for the state to break the "five only" policy. In talent evaluation, we can not only rely on diploma because it does not represent the teacher's capability. On the other hand, the university should pay more attention to the development of high-level university graduates. First-class universities have better teaching staff, scientific research conditions and discipline level. Graduation from first-class universities and first-class discipline university means that the teachers have more advantages in education and scientific research experience than other universities, and their research performance are supposed to be better on the whole. Therefore, when introducing talents, the school should carry out differentiated management and differentiated assessment for teachers at different levels of graduation according to the actual situation, strengthen later tracking and service, and improve the research vitality of the team. Because foreign university graduates receive foreign scientific research training, they may not adapt in project application, essay writing, social services and so on, which also exists in teaching work. The proportion of teaching workload of teachers who graduated from foreign universities is significantly lower than that of other teachers. Therefore, the cooperation between all teachers should be promoted through policy guidance, academic exchanges, and training, so that they can integrate research into the domestic teaching and research environment as soon as possible.

Finally, this study conducted multiple linear regression analysis on the overall data, and summarized the influence of variables such as age, professional title, etc. But it did not further classify the overall data. There may be many types of teachers with distinctive characteristics such as outstanding teaching ability, outstanding research ability and in other fields. The more accurate judgments can be obtained if the hierarchical classification and statistical analysis among the same and categories are adopted. The author will further advance the existing research under the conditions of future data permitting in order to obtain more accurate results. 


\section{References}

Andrea Bonaccorsi, Cinzia Daraio (2003), "Age Effects in Scientific Productivity: The Case of the Italian National Research Council", Scientometric 58, 49-90. http://doi.org/10.1023/A:1025427507552.

Brew Angela (1999), "Research and Teaching: Changing Relationships in a Changing Context", Studies in Higher Education 24, 291-301. http://doi.org/10.1080/03075079912331379905.

Burton R. Clark (1997), "The Modern Integration of Research Activities with Teaching and learning", Journal of Higher Education 68, 241-255. http://doi.org/10.2307/2960040.

Chen Jing, Wu Wei (2014), "An Exploration into Influencing Factors of Teachers' Perception of TeachingResearch Relationship in Teaching University", Research in Higher Education of Engineering 32, 97-102.

Feldman (1987), "Research productivity and scholarly accomplishment of college teachers as related to their instructional effectiveness: A review and exploration", Research in Higher Education 26, 227-238. http://doi.org/10.1007/BF00992241.

Huang Ya-ting (2015), "Globalization and the Reconstruction of Academic Identity: Contextual Change and Analysis Framework", Studies in Foreign Education 42, 86-97.

James S. Fairweather (2002), "The Mythologies of Faculty Productivity: Implications for Institutional Policy and Decision Making", Journal of Higher Education 73, 26-48. http://doi.org/10.1080/00221546.2002.11777129.

Jane Robertson, Carol Bond (2005), "Beyond the 'Research/Teaching nexus': Exploring the Complexity of Academic Experience", Higher Education 32, 509-535. http://doi.org/10.1080/03075070701476043.

Jaroslav Pelikan (2014), "The Idea of the University: A reexamination", Peiking University Press.

John Hattie, Marsh (1996), "The relationship between research and teaching: A meta analysis", Review of Educational Research 66,507-515. http://doi.org/10.3102/00346543066004507.

Kelly Coate, Ronaldo Barnett and Gareth Williams (2001), "Relationships between Teaching and Research in Higher Education in England", Higher Education Quarterly 55, 158-174. http://doi.org/10.1080/1356251960010102.

K Trigwell(2005), "Teaching-research Relations, Cross-disciplinary Collegiality and Student Learning", Higher Education 49, 235-254. http://doi.org/10.1007/s10734-004-6665-1.

Niu Feng-rui, Zhang Zi-wei (2017), "Preference of the Faculties for Teaching and Research and Its Influencing Factors", Modern Education Management 35, 53-58.

National Education Development Research Center (1994), "Trends of educational reform in developed countries", Peoples Education Press.

Paul Ramsdeni, Ingrid Moses (1992), "Associations between Research and Teaching in Australian Higher Education", Higher Education 23, 273-295. http://doi.org/10.1007/BF00145017.

RG Baldwin, CJ Lunceford and KE Vanderlinden (2005), "Faculty in the Middle Years: Illuminating an Overlooked Phase of Academic Life", Review of Higher Education 29, 97-118. http://doi.org/10.1353/rhe.2005.0055.

Robert T. Blackburn, Janet H. Lawrence (1986), "Aging and the Quality of Faculty Job Performance" , Review of Educational Research 3, 265-290.

Tan Zhi-song (2008). "The Comparative Study of University Development in the West and China", Journal of China Three Gorges University(Humanities \& Social Sciences) 30, 88-91.

Tien, F.F (2007), "Faculty Research Behavior and Career Incentives: The Case of Taiwan ", International Journal of Educational Development 27, 4-17. http://doi.org/10.1016/j.ijedudev.2006.04.014.

Tony Becher, Paul Trowler (2001), "Academic Tribes and Territories", Open University Press.

Wu Hong-fu (2011), "The Historical Context of the Research on the Relationship between Teaching and Scientific Research in China", Jiangsu Higher Education 36, 62-65.

Yu Xiu-lan (2008), "Research Teaching: A win-win Situation between Teaching and Scientific Research", Jiangsu Higher Education 33, 60-63.

Zhao Ting-ting (1992), "The Relationship between Teaching and Science: From the Perspective of the Contradiction between University and Society", Journal of Higher Education 12, 47-50.

Zhao Shi-hua, Zhang Jin-feng etc (2010), "Positive Factors of Female Teachers in Teaching and Scientific Research", Journal of Beijing Forestry University (Social Sciences) 9, 114-119.

Zhu Yi-na, He Guang-xi (2014), " Analysis of the Gender Sex Differences in Working Time and Research Time of University Faculty and Its Mediation Effect", Science and Social 4, 86-100.

Hong Ding was born in Zhejiang, China. He received master degree from the school of finance, Shanghai university of finance \& economics, Shanghai, in 2012. He is currently working in Zhejiang university of finance and economics, Hangzhou, China. His current research interests include scientific research management, teacher evaluation, academic evaluation, etc. 